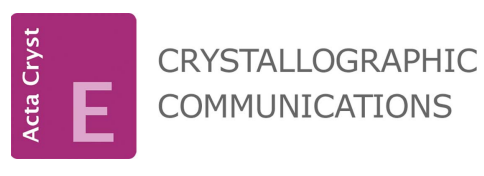

ISSN 2056-9890

Received 8 May 2019

Accepted 11 May 2019

Edited by W. T. A. Harrison, University of Aberdeen, Scotland

‡ Additional correspondence author, e-mail: edwardt@sunway.edu.my.

Keywords: crystal structure; sulfanyl; phenylethanone; Hirshfeld surface analysis; $\mathrm{NCl}$ plots; computational chemistry.

CCDC reference: 1915470

Supporting information: this article has supporting information at journals.iucr.org/e

\section{2-[(4-Bromophenyl)sulfanyl]-2-methoxy-1-phenyl- ethan-1-one: crystal structure, Hirshfeld surface analysis and computational chemistry}

\author{
Ignez Caracelli, ${ }^{a}$ Julio Zukerman-Schpector, ${ }^{b *}$ Henrique J. Traesel, ${ }^{c}$ Paulo R. \\ Olivato, ${ }^{\mathrm{c}}$ Mukesh M. Jotani ${ }^{\mathrm{d}}$ and Edward R. T. Tiekink ${ }^{\mathrm{e}} \neq$
}

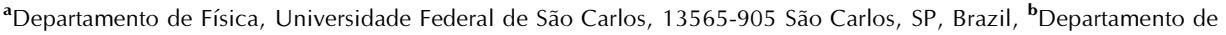 \\ Química, Universidade Federal de São Carlos, 13565-905 São Carlos, SP, Brazil, ' Instituto de Química, Universidade de \\ São Paulo, 05508-000 São Paulo, SP, Brazil, 'Department of Physics, Bhavan's Sheth R. A. College of Science, \\ Ahmedabad, Gujarat 380001, India, and ${ }^{\mathbf{e}}$ Research Centre for Crystalline Materials, School of Science and Technology, \\ Sunway University, 47500 Bandar Sunway, Selangor Darul Ehsan, Malaysia. *Correspondence e-mail: \\ julio@power.ufscar.br
}

The title compound, $\mathrm{C}_{15} \mathrm{H}_{13} \mathrm{BrO}_{2} \mathrm{~S}$, comprises three different substituents bound to a central (and chiral) methine-C atom, i.e. (4-bromophenyl)sulfanyl, benzaldehyde and methoxy residues: crystal symmetry generates a racemic mixture. A twist in the molecule is evident about the methine- $\mathrm{C}-\mathrm{C}$ (carbonyl) bond as evidenced by the $\mathrm{O}-\mathrm{C}-\mathrm{C}-\mathrm{O}$ torsion angle of $-20.8(7)^{\circ}$. The dihedral angle between the bromobenzene and phenyl rings is $43.2(2)^{\circ}$, with the former disposed to lie over the oxygen atoms. The most prominent feature of the packing is the formation of helical supramolecular chains as a result of methyland methine-C $-\mathrm{H} \cdots \mathrm{O}$ (carbonyl) interactions. The chains assemble into a three-dimensional architecture without directional interactions between them. The nature of the weak points of contacts has been probed by a combination of Hirshfeld surface analysis, non-covalent interaction plots and interaction energy calculations. These point to the importance of weaker $\mathrm{H} \cdots \mathrm{H}$ and $\mathrm{C}-\mathrm{H} \cdots \mathrm{C}$ interactions in the consolidation of the structure.

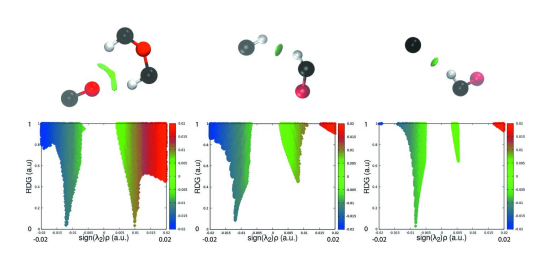

OPEN $\odot$ ACCESS

\section{Chemical context}

Recently, the crystal structure determination of the chloro analogue of the title compound was described (Caracelli et al., 2018). This was evaluated as a part of on-going studies into the conformational and electronic characteristics of various $\beta$-thiocarbonyl, $\beta$-bis-thiocarbonyl and $\beta$-thio- $\beta$-oxacarbonyl compounds, and their selenium counterparts, employing infrared spectroscopy, computational chemistry and X-ray crystallographic methods (Vinhato et al., 2013; ZukermanSchpector et al., 2015; Caracelli et al., 2015; Traesel et al., 2018). In particular, the evaluation of the anti-inflammatory activity of what could be selective COX-2 inhibitors (Cerqueira et al., 2017) motivates these investigations, which are supported by molecular docking studies designed to ascertain the mechanism(s) of inhibition (Baptistini, 2015). Subsequently, crystals of the title bromo analogue (I) were obtained: the crystal structure is reported herein along with an analysis of the calculated Hirshfeld surfaces, non-covalent interaction plots (for selected interactions) as well as a computational chemistry study. 


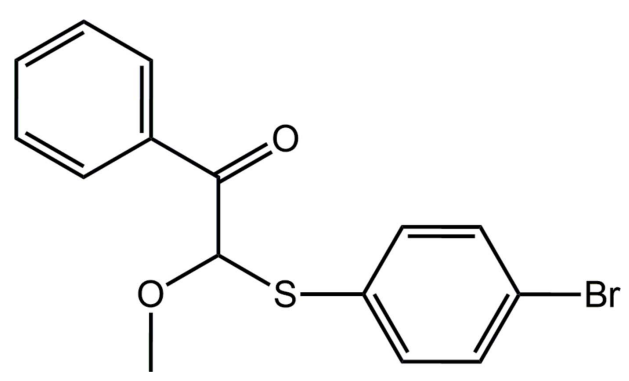

\section{Structural commentary}

The molecular structure of (I), Fig. 1, is isostructural with the previously described chloro analogue, (II) (Caracelli et al., 2018). Here, the central chiral methine-C 8 atom is connected to (4-bromophenyl)sulfanyl, phenylethanone and methoxy groups. There is a twist in the ethanone residue as seen in the value of the $\mathrm{O} 1-\mathrm{C} 8-\mathrm{C} 9-\mathrm{O} 2$ torsion angle of $-20.8(7)^{\circ}$, with the oxygen atoms being approximately syn. The dihedral angle between the bromobenzene and phenyl rings is $43.2(2)^{\circ}$, indicative of an inclined relative disposition. Globally, the bromobenzene ring is orientated towards the ethanone residue.

The geometric parameters in (I) can be compared with those of (II): the twist about the central $\mathrm{C} 8-\mathrm{C} 9$ bond is approximately the same in (II), i.e. the the $\mathrm{O} 1-\mathrm{C} 8-\mathrm{C} 9-\mathrm{O} 2$ torsion angle is $19.3(7)^{\circ}$, as is the dihedral angle of $42.9(2)^{\circ}$ between the aromatic rings. The overlay diagram in Fig. 2 highlights the close similarity between the molecular structures of (I) and (II).

\section{Supramolecular features}

The main feature of the molecular packing of (I) is the presence of $\mathrm{C}-\mathrm{H} \cdots \mathrm{O}$ interactions where the carbonyl-O2

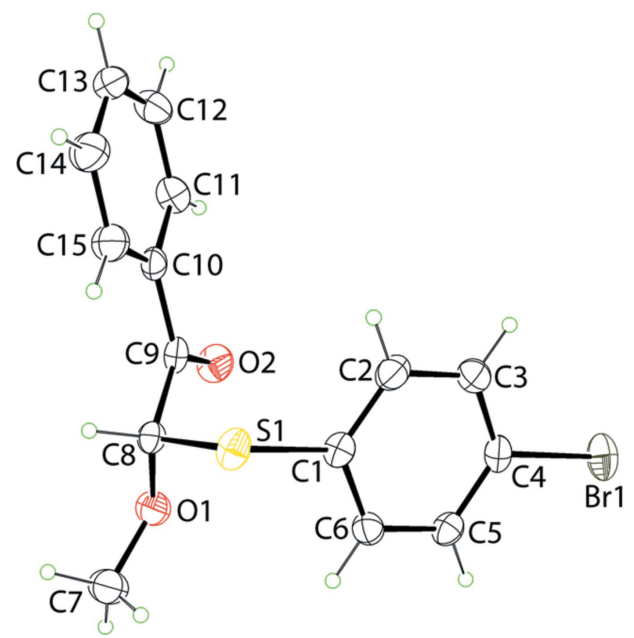

Figure 1

The molecular structure of (I), showing the atom-labelling scheme and displacement ellipsoids at the $25 \%$ probability level.

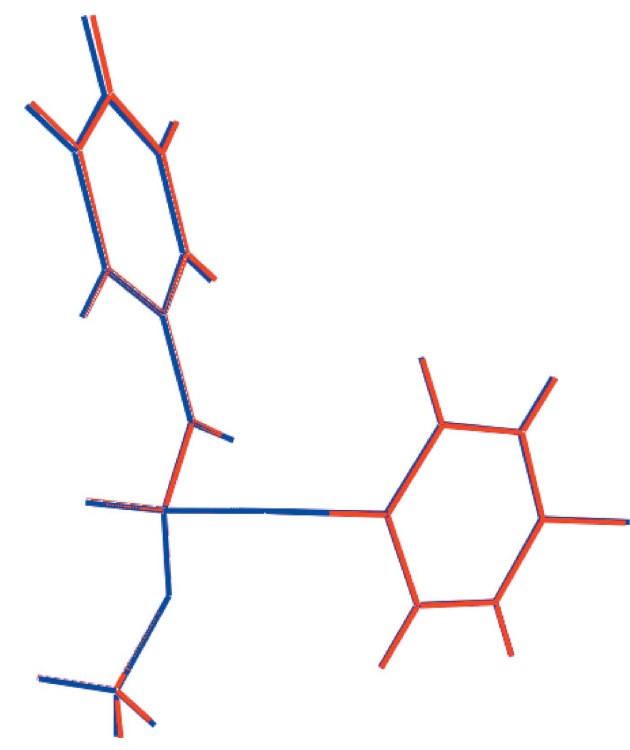

Figure 2

Overlay diagram of (I) (red image) and (II) (blue image).

atom accepts two contacts from methyl-C7-H and methineC8-H atoms derived from the same molecule to generate sixmembered $\{\cdots \mathrm{O} \cdots \mathrm{HCOCH}\}$ synthons, Table 1 . The result is a supramolecular chain propagating along [001] with an helical topology ( $2_{1}$ symmetry), Fig. 3(a). The chains pack without directional interactions between them, Fig. $3(b)$.

(a)

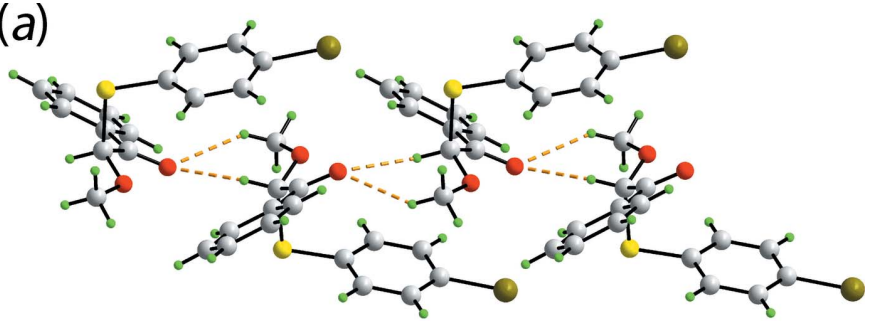

(b)

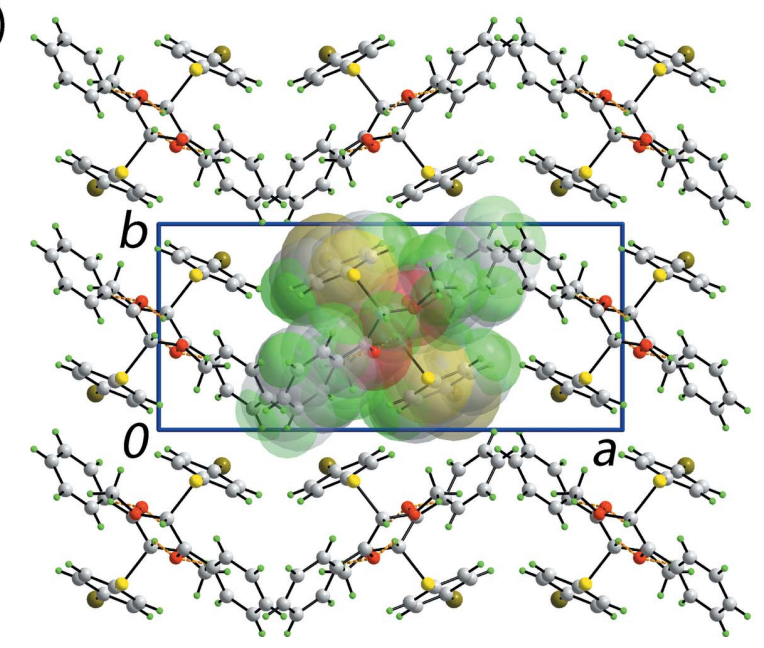

Figure 3

Molecular packing in (I): (a) view of the helical supramolecular chain parallel to the $c$ axis sustained by $\mathrm{C}-\mathrm{H} \cdots \mathrm{O}$ interactions shown as orange dashed lines and $(b)$ view of the unit-cell contents shown in projection down the $c$ axis; one chain is highlighted in space-filling mode. 
Table 1

Hydrogen-bond geometry $\left(\AA,^{\circ}\right)$.

\begin{tabular}{lllll}
\hline$D-\mathrm{H} \cdots A$ & $D-\mathrm{H}$ & $\mathrm{H} \cdots A$ & $D \cdots A$ & $D-\mathrm{H} \cdots A$ \\
\hline $\mathrm{C} 7-\mathrm{H} 7 A \cdots \mathrm{O} 2^{\mathrm{i}}$ & 0.96 & 2.47 & $3.296(9)$ & 144 \\
$\mathrm{C} 8-\mathrm{H} 8 \cdots \mathrm{O} 2^{\mathrm{i}}$ & 0.98 & 2.44 & $3.331(6)$ & 150 \\
\hline
\end{tabular}

Symmetry code: (i) $-x+1,-y+1, z+\frac{1}{2}$.

\section{Hirshfeld surface analysis}

The Hirshfeld surface calculations for (I) were performed in accord with protocols described recently (Tan et al., 2019) employing Crystal Explorer (Turner et al., 2017). Over and above the analysis of the important surface contacts in the crystal of (I), the results are compared with those for the recently determined isostructural chloro analogue (II) (Caracelli et al., 2018). The crystal of (I) has similar intermolecular $\mathrm{C}-\mathrm{H}$...O interactions (Table 1) and short interatomic $\mathrm{H} \cdots \mathrm{H}, \mathrm{C} \cdots \mathrm{H}$ and $\mathrm{C} \cdots \mathrm{C}$ contacts (Table 2) as in isostructural (II), as detailed below.

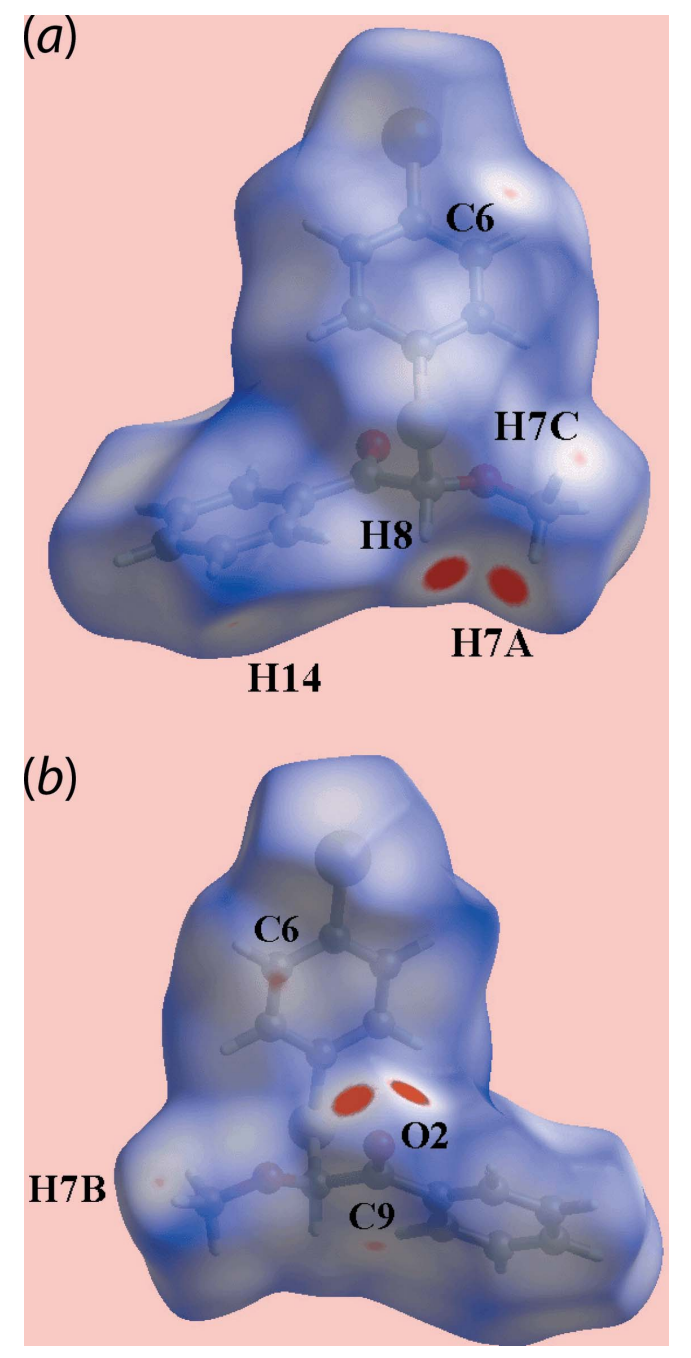

Figure 4

Two views of the Hirshfeld surface for (I) mapped over $d_{\text {norm }}$ in the range -0.084 to +1.422 arbitrary units.
Table 2

Summary of short interatomic contacts (A) in (I) and (II).

\begin{tabular}{|c|c|c|}
\hline Contact & Distance & Symmetry operation \\
\hline & (I) & \\
\hline $\mathrm{H} 7 B \cdots \mathrm{H} 14$ & 2.15 & $1-x,-y,-\frac{1}{2}+z$ \\
\hline $\mathrm{H} 7 \mathrm{C} \cdots \mathrm{C} 6$ & 2.74 & $1-x, 2-y, \frac{1}{2}+z$ \\
\hline $\mathrm{H} 12 \cdots \mathrm{Br} 1$ & 3.02 & $\frac{1}{2}-x,-1+y, \frac{1}{2}+z$ \\
\hline \multirow[t]{2}{*}{$\mathrm{C} 6 \cdots \mathrm{C} 9$} & $3.355(8)$ & $1-x, 1-y,-\frac{1}{2}+z$ \\
\hline & (II) & \\
\hline $\mathrm{H} 7 B \cdots \mathrm{H} 14$ & 2.10 & $1-x,-y, \frac{1}{2}+z$ \\
\hline $\mathrm{H} 7 B \cdots \mathrm{C} 14$ & 2.76 & $1-x,-y, \frac{1}{2}+z$ \\
\hline $\mathrm{H} 7 C \cdots \mathrm{C} 6$ & 2.73 & $1-x, 1-y, \frac{1}{2}+z$ \\
\hline $\mathrm{C} 6 \cdots \mathrm{C} 9$ & $3.334(9)$ & $1-x,-y, \frac{1}{2}+z$ \\
\hline
\end{tabular}

Notes: (a) The interatomic distances are calculated in Crystal Explorer (Turner et al., 2017) whereby the $X-\mathrm{H}$ bond lengths are adjusted to their neutron values.

The intermolecular contacts in (I), Tables 1 and 2, are characterized as the pair of bright-red spots near the carbonyl$\mathrm{O} 2$ atom, and each of the methyl-H7 $A$ and methine-H8 atoms on the Hirshfeld surfaces mapped over $d_{\text {norm }}$ in the images of Fig. 4. Further, interactions are indicated by the faint-red spots

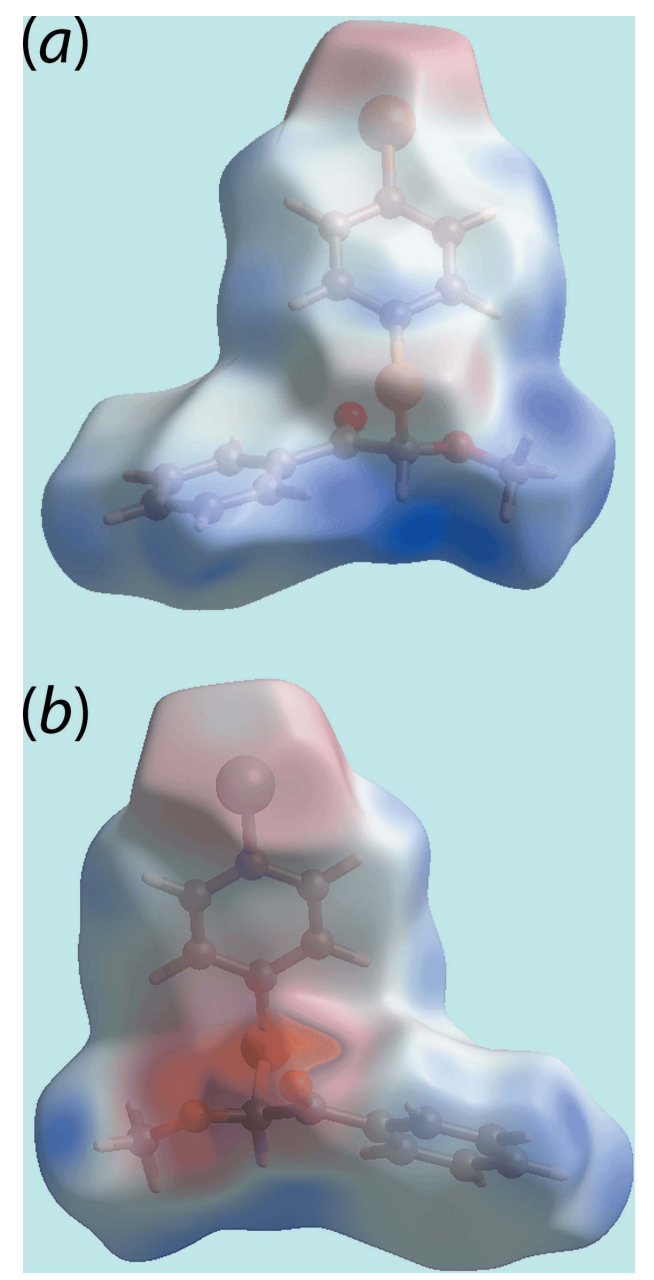

Figure 5

Two views of the Hirshfeld surface for (I) mapped over the electrostatic potential in the range -0.074 to +0.053 atomic units. The red and blue regions represent negative and positive electrostatic potentials, respectively. 


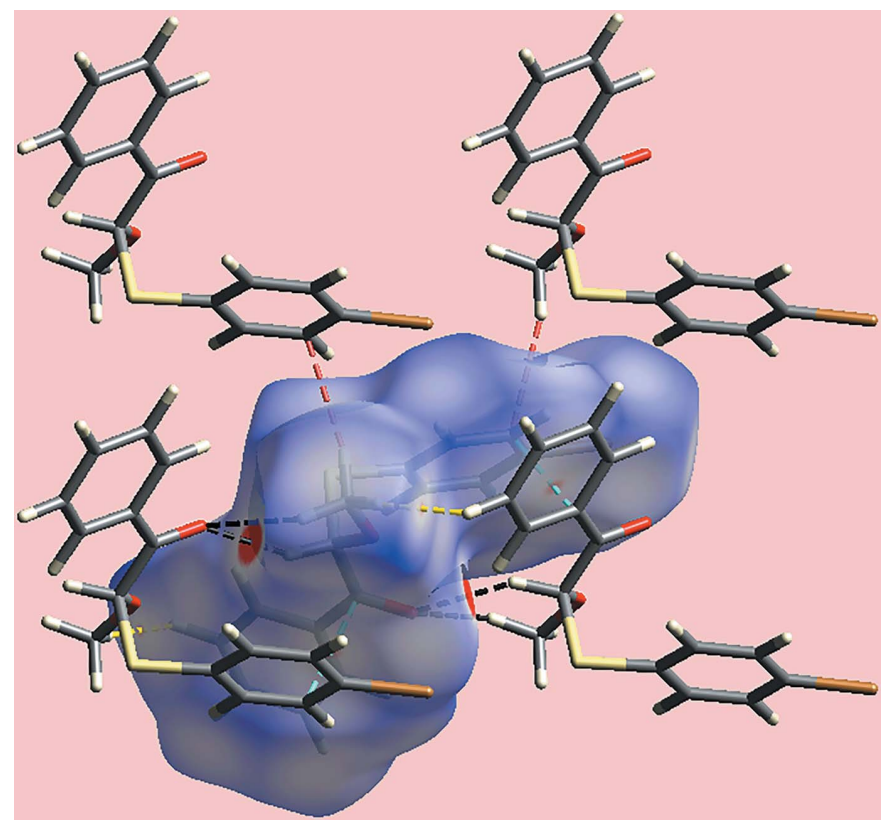

Figure 6

A view of the Hirshfeld surface for (I) mapped over $d_{\text {norm }}$ in the range -0.084 to +1.422 arbitrary units highlighting intermolecular $\mathrm{C}-\mathrm{H} \cdots \mathrm{O}$, $\mathrm{C} \cdots \mathrm{C}, \mathrm{H} \cdots \mathrm{H}$ and $\mathrm{C} \cdots \mathrm{H} / \mathrm{H} \cdots \mathrm{C}$ contacts by black, red, yellow and skyblue dashed lines, respectively.

near the methyl-H7B and $\mathrm{H} 7 C$, phenyl-H14, bromobenzene$\mathrm{C} 6$ and carbonyl-C9 atoms in Fig. 4. On the Hirshfeld surfaces mapped over the calculated electrostatic potential in the images of Fig. 5, the donors and acceptors of intermolecular interactions are viewed as blue and red regions around the participating atoms corresponding to positive and negative potentials, respectively. The environment around a reference molecule within the $d_{\text {norm }}$-mapped Hirshfeld surface high- (a)

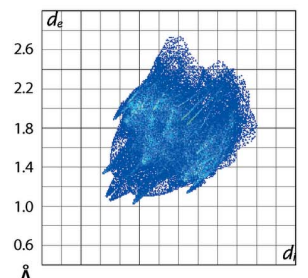

$\AA$

(d)

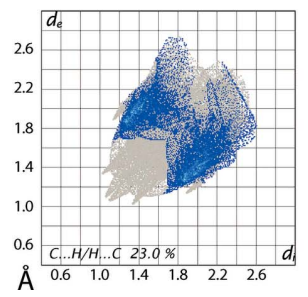

(b)

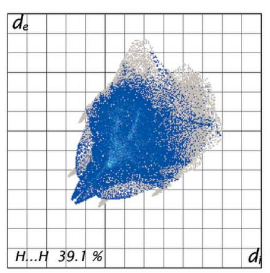

(e)

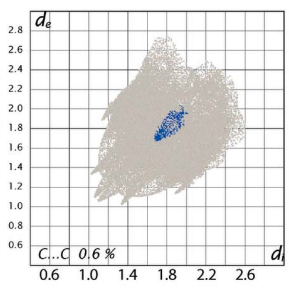

(c)

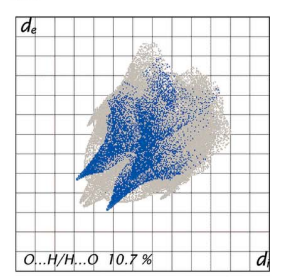

(f)

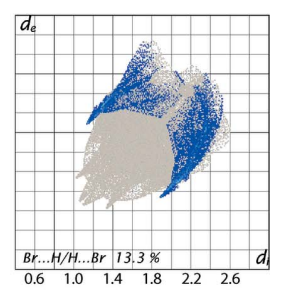

Figure 7

(a) The full two-dimensional fingerprint plot for $(\mathrm{I})$ and $(b)-(f)$ those delineated into $\mathrm{H} \cdots \mathrm{H}, \mathrm{O} \cdots \mathrm{H} / \mathrm{H} \cdots \mathrm{O}, \mathrm{C} \cdots \mathrm{H} / \mathrm{H} \cdots \mathrm{C}, \mathrm{C} \cdots \mathrm{C}$ and $\mathrm{Br} \cdots \mathrm{H} /$ $\mathrm{H} \cdots \mathrm{Br}$ contacts.
Table 3

Percentage contributions of interatomic contacts to the Hirshfeld surface for (I) and (II).

\begin{tabular}{lll}
\hline Contact & Percentage contribution & \\
\hline & $(\mathrm{I}), X=\mathrm{Br}$ & $(\mathrm{II}), X=\mathrm{Cl}$ \\
$\mathrm{H} \cdots \mathrm{H}$ & 39.3 & 39.1 \\
$\mathrm{O} \cdots \mathrm{H} / \mathrm{H} \cdots \mathrm{O}$ & 11.0 & 10.7 \\
$\mathrm{C} \cdots \mathrm{H} / \mathrm{H} \cdots \mathrm{C}$ & 23.2 & 23.0 \\
$X \cdots \mathrm{H} / \mathrm{H} \cdots \mathrm{X}$ & 12.8 & 13.3 \\
$\mathrm{~S} \cdots \mathrm{H} / \mathrm{H} \cdots \mathrm{S}$ & 4.4 & 4.3 \\
$X \cdots \mathrm{S} / \mathrm{S} \cdots X$ & 2.1 & 2.3 \\
$X \cdots \mathrm{O} / \mathrm{O} \cdots X$ & 2.1 & 2.1 \\
$\mathrm{C} \cdots \mathrm{O} / \mathrm{O} \cdots \mathrm{C}$ & 1.5 & 1.5 \\
$\mathrm{C} \cdots X / X \cdots \mathrm{C}$ & 1.5 & 1.8 \\
$\mathrm{C} \cdots \mathrm{S} / \mathrm{S} \cdots \mathrm{C}$ & 1.2 & 1.1 \\
$\mathrm{C} \cdots \mathrm{C}$ & 0.6 & 0.6 \\
\hline
\end{tabular}

lighting the intermolecular $\mathrm{C}-\mathrm{H} \cdots \mathrm{O}$ interactions and short interatomic $\mathrm{H} \cdots \mathrm{H}, \mathrm{C} \cdots \mathrm{H} / \mathrm{H} \cdots \mathrm{C}$ and $\mathrm{C} \cdots \mathrm{C}$ contacts is illustrated in Fig. 6.

From the overall two-dimensional fingerprint plot in Fig. 7(a), and also those delineated into $\mathrm{H} \cdots \mathrm{H}, \mathrm{O} \cdots \mathrm{H} / \mathrm{H} \cdots \mathrm{O}$, $\mathrm{C} \cdots \mathrm{H} / \mathrm{H} \cdots \mathrm{C}, \mathrm{C} \cdots \mathrm{C}$ and $\mathrm{Br} \cdots \mathrm{H} / \mathrm{H} \cdots \mathrm{Br}$ contacts in Fig. $7(b)$ $(f)$, respectively, it is evident that the plots are basically identical in shape to those calculated for the chloro analogue (II) with only slight differences in the distribution of points (Caracelli et al., 2018). The percentage contributions from the different interatomic contacts to the Hirshfeld surfaces of (I) and (II) are summarized in Table 3; these values again highlight the similarities between (I) and (II).

The $\mathrm{C}-\mathrm{H} \cdots \mathrm{O}$ contacts significant in the crystal of (I), Table 1 , are represented as the pair of spikes at $d_{\mathrm{e}}+d_{\mathrm{i}} \sim 2.3 \AA$ in the fingerprint plot delineated into $\mathrm{O} \cdots \mathrm{H} / \mathrm{H} \cdots \mathrm{O}$ contacts, Fig. $7(c)$. The short interatomic $\mathrm{H} \cdots \mathrm{H}, \mathrm{C} \cdots \mathrm{H} / \mathrm{H} \cdots \mathrm{C}$ and C. . C contacts (Table 2) are characterized as pair of beakshape tips at $d_{\mathrm{e}}+d_{\mathrm{i}} \sim 2.1 \AA$, Fig. 7(b), and forceps at $d_{\mathrm{e}}+d_{\mathrm{i}}$ $\sim 2.8 \AA$, Fig. 7(d), and vase-shaped distribution of points at $d_{\mathrm{e}}$ $+d_{\mathrm{i}} \sim 3.3 \AA$, Fig. 7(e), in the respective delineated fingerprint plots. In addition to these contacts, the crystal also features short interatomic $\mathrm{Br} \cdots \mathrm{H} / \mathrm{H} \cdots \mathrm{Br}$ contacts appearing as the pair of forceps-like tips at $d_{\mathrm{e}}+d_{\mathrm{i}} \sim 3.0 \AA$ in the delineated fingerprint plot of Fig. 7(f). The small contribution from other remaining interatomic contacts summarized in Table 3 have a negligible effect on the packing.

\section{Interaction energies}

The pairwise interaction energies between the molecules within the crystal are calculated by the summation of four energy components comprising electrostatic $\left(E_{\text {ele }}\right)$, polarization $\left(E_{\mathrm{pol}}\right)$, dispersion $\left(E_{\mathrm{dis}}\right)$ and exchange-repulsion $\left(E_{\mathrm{rep}}\right)$ (Turner et al., 2017). These energies were obtained by using the wave function calculated at the HF/STO-3G level theory for each of (I) and (II). The individual energy components as well as total interaction energy relative to reference molecule within the molecular cluster were calculated. Table 4 summarizes quantitatively the strength and nature of intermolecular interactions in the crystals of (I) and (II). 
Table 4

Summary of interaction energies $\left(\mathrm{kJ} \mathrm{mol}^{-1}\right)$ calculated for (I) and (II).

\begin{tabular}{lllllll}
\hline Contact & $R(\AA)$ & $E_{\text {ele }}$ & $E_{\text {pol }}$ & $E_{\text {dis }}$ & $E_{\text {rep }}$ & $E_{\text {tot }}$ \\
\hline
\end{tabular}

(I)

$\mathrm{C} 7-\mathrm{H} 7 A \cdots \mathrm{O} 2^{\mathrm{i}}+$

$\mathrm{C} 8-\mathrm{H} 8 \cdots \mathrm{O} 2^{\mathrm{i}}+$

$\mathrm{H} 7 B \cdots \mathrm{H} 14^{\mathrm{i}}+$

C6 $\cdots \mathrm{C} 9^{\mathrm{i}}$

$\mathrm{H} 7 \mathrm{C} \cdots \mathrm{C} 6^{\mathrm{ii}}$

$\mathrm{H} 12 \cdots \mathrm{Br}^{\mathrm{ii}}$

$\begin{array}{llllll}6.40 & -20.0 & -12.1 & -53.2 & 34.0 & -48.0 \\ 8.75 & -7.0 & -1.2 & -16.7 & 9.3 & -15.4 \\ 10.83 & -4.1 & -0.9 & -12.9 & 6.4 & -11.2\end{array}$

(II)

$\mathrm{C} 7-\mathrm{H} 7 A \cdots \mathrm{O} 2^{\mathrm{iii}}+$

$\mathrm{C} 8-\mathrm{H} 8 \cdots \mathrm{O} 2^{\mathrm{iii}}+$

$\mathrm{H} 7 B \cdots \mathrm{H} 14^{\mathrm{iii}}+$

$\mathrm{C} 6 \cdot \cdots \mathrm{C} 9^{\mathrm{iii}}+$

$\begin{array}{lllllll}\mathrm{H} 7 B \cdots \mathrm{C} 14^{\mathrm{iii}} & 6.13 & -19.5 & -11.8 & -52.7 & 35.1 & -46.6\end{array}$

\begin{tabular}{lllllll}
$\mathrm{H} 7 \mathrm{C} \cdots \mathrm{C}^{\mathrm{iv}}$ & 9.06 & -6.6 & -1.4 & -14.5 & 8.2 & -14.0 \\
\hline
\end{tabular}

Notes: Symmetry operations: (i) $1-x, 1-y,-\frac{1}{2}+z$; (ii) $1-x, 2-y, \frac{1}{2}+z$; (iii) $1-x,-y$, $\frac{1}{2}+z ;$ (iv) $1-x, 1-y, \frac{1}{2}+z$.

It is observed from the interaction energies calculated between the reference molecule and the symmetry-related molecules at $R=6.40$ and $6.13 \AA$ (where $R$ is the separation of the centres of gravity of the molecules), respectively (Table 4), that the almost identical values of the electrostatic energy component are due to intermolecular $\mathrm{C}-\mathrm{H} \cdots \mathrm{O}$ interactions whereas the dispersive components are dominant owing to the short interatomic contacts between the same molecules. The other short interatomic $\mathrm{C} \cdots \mathrm{H} / \mathrm{H} \cdots \mathrm{C}$ contact between the methyl-H7C and phenyl-C6 atoms in (I) and (II), and the
$\mathrm{H} 12 \cdots \mathrm{Br} 1$ contact in (I) have a major contribution from dispersion components.

The magnitudes of intermolecular energies are represented graphically in the energy frameworks for (I) and (II) viewed down the $c$ axes are shown in Fig. 8. Here, the supramolecular architecture of the crystals is represented as cylinders joining centroids of molecular pairs. The red, green and blue coloration represent the energy components $E_{\text {ele }}, E_{\text {disp }}$ and $E_{\text {tot }}$, respectively. The radius of the cylinder is proportional to the magnitude of interaction energy which are adjusted to the same scale factor $\left(3 \mathrm{~kJ} \mathrm{~mol}^{-1}\right)$ within $4 \times 4 \times 4$ unit cells. From the energy frameworks for (I) and (II) illustrated in Fig. 8, it is clearly evident that the supramolecular associations viewed down the $c$ axis are identical, reflecting the isostructural relationship between (I) and (II).

\section{Non-covalent interaction plots}

The non-covalent interaction plot (NCIplot) analysis was used in the present study in order to confirm the attractive nature of some of the specified intermolecular contacts (ContrerasGarcía et al., 2011). This method is based on the electron density and its derivatives allowing the visualization of the gradient isosurfaces. The colour-based isosurfaces correspond to the values of $\operatorname{sign}\left(\lambda^{2}\right) \rho(\mathrm{r})$, where $\rho$ is the electron density and $\lambda^{2}$ is the second eigenvalue of the Hessian matrix of $\rho$ (Johnson et al., 2010). The isosurfaces for the interactions (a)
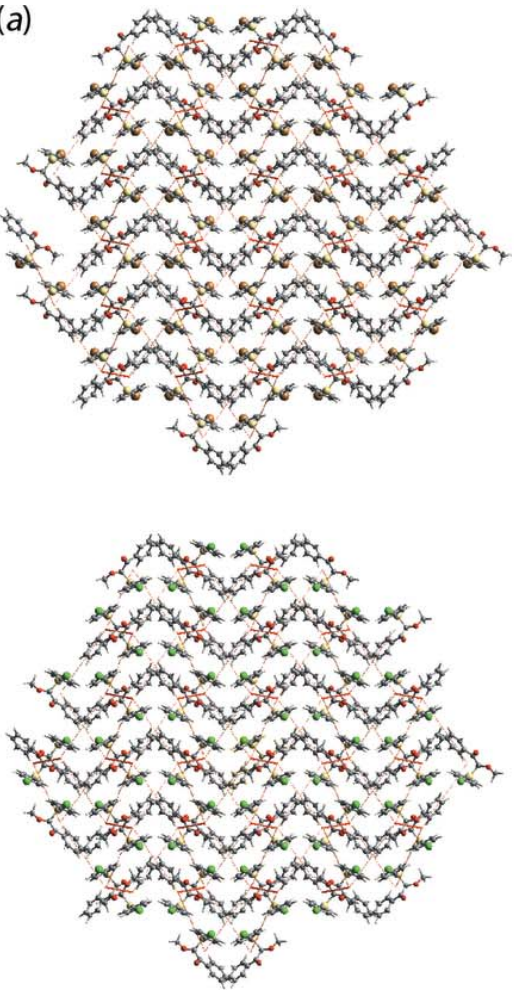

(b)
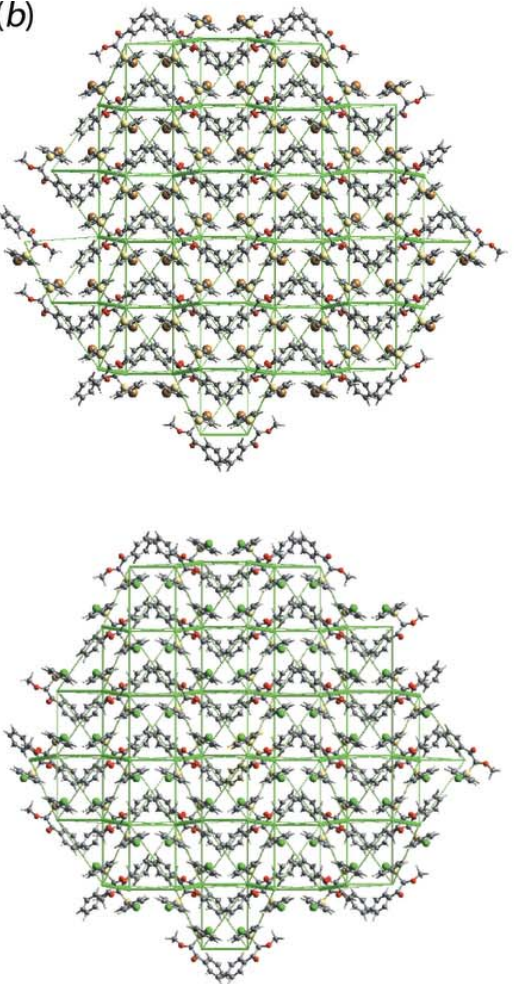
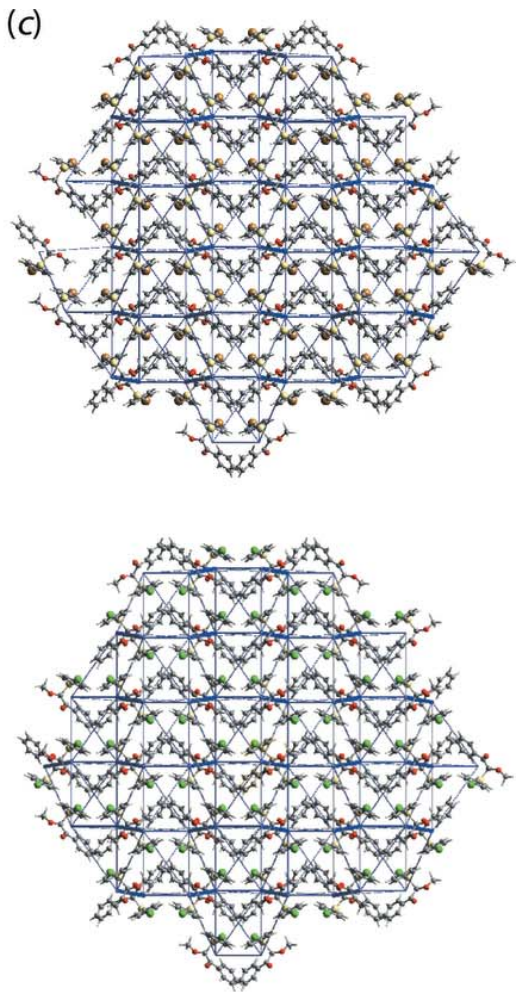

Figure 8

A comparison of the energy frameworks, plotted with the same scale, composed of $(a)$ electrostatic potential force, $(b)$ dispersion force and $(c)$ total energy for the molecules of (I), upper images, and (II), lower images, all viewed down the $c$-axis direction. same scale factor of 50 with a cut-off value of $3 \mathrm{~kJ} \mathrm{~mol}^{-1}$ within $4 \times 4 \times 4$ unit cells. 


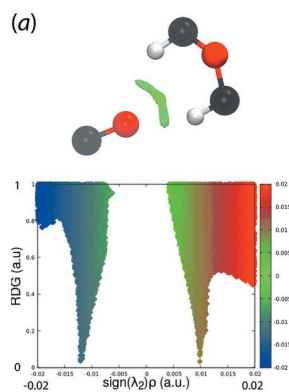

(b)

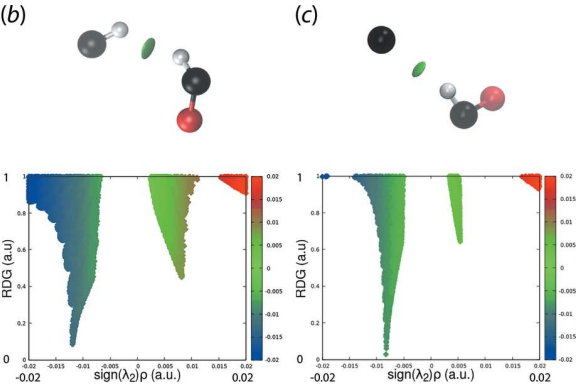

Figure 9

Non-covalent interaction plots for intermolecular interactions between (a) each of the methyl-C7- and methine-C- $\mathrm{H}$ atoms and the carbonyl-O2 atom, $(b)$ the methyl-H7B and phenyl-H14 atoms and $(c)$ bromobenzene$\mathrm{C} 6$ and methyl-H7C atoms.

between the carbonyl-O2 and each of the methyl-H7B and phenyl-H14 atoms, the H7B and H14 atoms, and the chlorobenzene-C6 and methyl-H7C atoms are shown in the upper views of Fig. 9(a)-(c), respectively. The green isosurface observed in each of these indicates a weakly attractive interaction as opposed to attractive (blue isosurface) or repulsive (red). The lower views of Fig. 9, where the plots of the RDG versus $\operatorname{sign}\left(\lambda^{2}\right) \rho(\mathrm{r})$ are depicted, the non-covalent interaction peaks appear at density values equal or lower than 0.01 a.u., consistent with weakly attractive interactions.

\section{Database survey}

There are three literature structures related to (I), namely the already mentioned (II) (NIBTAW; Caracelli et al., 2018), the S-bound 4-methoxybenzene derivative [(III); JUPLOZ; Caracelli et al., 2015] and the S-bound 4-tolyl species [NOVGIQ; (IV); Zukerman-Schpector et al., 2015] derivatives. All four compounds crystallize in the orthorhombic space group $P c a 2_{1}$ and are isostructural. The differences between the molecules of (I)-(IV) relates to the relative orientations of the S-bound methoxybenzene ring in (III). This comes about owing to a twist about the $\mathrm{C} 8-\mathrm{S} 1$ bond as manifested in the $\mathrm{C} 4-\mathrm{S} 1-\mathrm{C} 8-\mathrm{C} 9$ torsion angles of 57.1 (4), 57.3 (5), 46.6 (3) and 57.9 (3) ${ }^{\circ}$ for (I)-(IV), respectively. This difference notwithstanding, the angles between the S-bound benzene rings and the phenyl rings in (I)-(IV) span a relatively narrow range of values, i.e. 43.2 (2), 42.9 (2), 40.11 (16) and $44.03(16)^{\circ}$, respectively.

\section{Synthesis and crystallization}

Firstly, 4'-bromothiophenol $(10.0 \mathrm{~g}, 52.9 \mathrm{mmol})$ was reacted with bromine $(3.1 \mathrm{ml}, 56.0 \mathrm{mmol})$ in dichloromethane $(400 \mathrm{ml})$ on a hydrated silica gel support $\left(50 \mathrm{~g}\right.$ of $\mathrm{SiO}_{2}$ and water $(30 \mathrm{ml})$ to give $4^{\prime}$-bromophenyl disulfide $(8.0 \mathrm{~g}$, yield $80 \%)$. A brown solid was obtained after filtration and evaporation without further purification (Ali \& McDermott, 2002). Then, a solution of 2-methoxy acetophenone (Sigma-Aldrich; $1.0 \mathrm{ml}$, $7.3 \mathrm{mmol})$ in THF $(25 \mathrm{ml})$, was added dropwise to a cooled
Table 5

Experimental details.

\begin{tabular}{ll}
\hline Crystal data & \\
Chemical formula & $\mathrm{C}_{15} \mathrm{H}_{13} \mathrm{BrO}_{2} \mathrm{~S}$ \\
$M_{\mathrm{r}}$ & 337.21 \\
Crystal system, space group & Orthorhombic, $P c a 2_{1}$ \\
Temperature (K) & 293 \\
$a, b, c(\AA)$ & $18.0683(13), 8.0190(6), 9.8513(5)$ \\
$V\left(\AA^{3}\right)$ & $1427.35(16)$ \\
$Z$ & 4 \\
Radiation type & Mo $K \alpha$ \\
$\mu\left(\mathrm{mm}^{-1}\right)$ & 3.02 \\
Crystal size $(\mathrm{mm})$ & $0.47 \times 0.20 \times 0.14$
\end{tabular}

Data collection

Diffractometer

Absorption correction

$T_{\min }, T_{\max }$

No. of measured, independent and observed $[I>2 \sigma(I)]$ reflections

$R_{\text {int }}$

$(\sin \theta / \lambda)_{\max }\left(\AA^{-1}\right)$

Bruker APEXII CCD
Multi-scan $(S A D A B S ;$ Sheldrick,
1996)
$0.545,0.745$
$6329,2820,1903$
0.037
0.625

$0.035,0.086,0.90$
2820
173
1
H-atom parameters constrained
$0.24,-0.36$
Flack $x$ determined using 702
$\quad$ quotients $\left[\left(I^{+}\right)-\left(I^{-}\right)\right] /\left[\left(I^{+}\right)+\left(I^{-}\right)\right]$
$\quad($ Parsons et al., 2013$)$
$0.013(11)$

Refinement

$R\left[F^{2}>2 \sigma\left(F^{2}\right)\right], w R\left(F^{2}\right), S$

No. of reflections

No. of parameters

No. of restraints

$\mathrm{H}$-atom treatment

$\Delta \rho_{\max }, \Delta \rho_{\min }\left(\mathrm{e} \AA^{-3}\right)$

Absolute structure

Absolute structure parameter $0.013(11)$

Computer programs: APEX2 and SAINT (Bruker, 2009), SIR2014 (Burla et al., 2015), SHELXL2014 (Sheldrick, 2015), ORTEP-3 for Windows (Farrugia, 2012), DIAMOND (Brandenburg, 2006), MarvinSketch (ChemAxon, 2010) and publCIF (Westrip, 2010).

$(195 \mathrm{~K})$ solution of diisopropylamine $(1.1 \mathrm{ml}, 8.0 \mathrm{mmol})$ and $n$-butyllithium $(5.4 \mathrm{ml}, 7.3 \mathrm{mmol})$ in THF $(30 \mathrm{ml})$. After 30 mins, a solution of $4^{\prime}$-bromophenyl disulfide $(2.8 \mathrm{~g}, 7.3 \mathrm{mmol})$ with hexamethylphosphoramide (HMPA) (1.3 ml, $c a$ $7.3 \mathrm{mmol}$ ) dissolved in THF (35 ml) was added dropwise to the enolate solution (Zoretic \& Soja, 1976). After stirring for $3 \mathrm{~h}$, water $(70 \mathrm{ml})$ was added at room temperature and extraction with diethyl ether ensued. The organic layer was then treated with a saturated solution of ammonium chloride until neutral $\mathrm{pH}$ was reached and then dried over anhydrous magnesium sulfate. A brown oil was obtained after evaporation of the solvent. Purification through flash chromatography with $n$-hexane was used in order to remove the non-polar reactant (disulfide), then with dry acetone to give a mixture of both acetophenones (product and reactant). Crystallization was performed by vapour diffusion of $n$-hexane into a chloroform solution held at $283 \mathrm{~K}$ to give the pure product $(0.6 \mathrm{~g}$, yield $=70 \%)$. Irregular colourless crystals suitable for $\mathrm{X}$-ray diffraction of (I) were obtained by the same pathway. M.p. $357.0-357.5 \mathrm{~K} .{ }^{1} \mathrm{H}$ NMR $\left(\mathrm{CDCl}_{3}, 500 \mathrm{MHz}, \delta\right.$ ppm): 3.67 $(s, 3 \mathrm{H}), 5.87(s, 1 \mathrm{H}), 7.20-7.23(m, 2 \mathrm{H}), 7.39-7.41(m, 2 \mathrm{H})$, 7.44-7.47 (m, 2H), 7.57-7.62 (m, 1H), 7.92-7.94 $(m, 2 \mathrm{H}) .{ }^{13} \mathrm{C}$ NMR $\left(\mathrm{CDCl}_{3}, 125 \mathrm{MHz}, \delta\right.$ p.p.m.): $190.16,135.73,134.18$, 133.53, 132.13, 129.92, 128.81, 128.57, 123.41, 89.28, 56.10. Microanalysis calculated for $\mathrm{C}_{15} \mathrm{H}_{13} \mathrm{BrO}_{2} \mathrm{~S}$ (\%): C 53.42, H 
3.89. Found (\%): C 53.19, H 3.85. High-Resolution MS $\left[M^{+}\right.$, $M^{2+}$ ] calculated: $335.9820,337.9799$; found: $335.9797,337.9778$.

\section{Refinement details}

Crystal data, data collection and structure refinement details are summarized in Table 5. The carbon-bound $\mathrm{H}$ atoms were placed in calculated positions $(\mathrm{C}-\mathrm{H}=0.93-0.98 \AA)$ and were included in the refinement in the riding-model approximation, with $U_{\text {iso }}(\mathrm{H})$ set to $1.2-1.5 U_{\text {eq }}(\mathrm{C})$. The absolute structure was determined based on differences in Friedel pairs included in the data set (Parsons et al., 2013).

\section{Acknowledgements}

Professor Regina H. A. Santos from IQSC-USP for the X-ray data collection.

\section{Funding information}

The Brazilian agencies São Paulo Research Foundation (FAPESP), for financial support of this research, Coordination for the Improvement of Higher Education Personnel, for a scholarship to to HJT (CAPES 3300201191P0 and Finance Code 001), and the National Council for Scientific and Technological Development, for fellowships (CNPq: 308480/20163 to IC; 303207/2017-5 to JZ-S; 301180/2013-0 to PRO), are gratefully acknowledged. Crystallographic research at Sunway University is supported by Sunway University Sdn Bhd (grant. No. STR-RCTR-RCCM-001-2019).

\section{References}

Ali, M. H. \& McDermott, M. (2002). Tetrahedron Lett. 43, 6271-6273. Baptistini, N. (2015). Ph. D. Thesis, Federal University of São Carlos, São Carlos, Brazil. available online at: https://repositorio. ufscar. br/ handle/ufscar/7554.
Brandenburg, K. (2006). DIAMOND. Crystal Impact GbR, Bonn, Germany.

Bruker (2009). APEX2 and SAINT. Bruker AXS Inc., Madison, Wisconsin, USA

Burla, M. C., Caliandro, R., Carrozzini, B., Cascarano, G. L., Cuocci, C., Giacovazzo, C., Mallamo, M., Mazzone, A. \& Polidori, G. (2015). J. Appl. Cryst. 48, 306-309.

Caracelli, I., Olivato, P. R., Traesel, H. J., Valença, J., Rodrigues, D. N. S. \& Tiekink, E. R. T. (2015). Acta Cryst. E71, o657-o658.

Caracelli, I., Zukerman-Schpector, J., Traesel, H. J., Olivato, P. R., Jotani, M. M. \& Tiekink, E. R. T. (2018). Acta Cryst. E74, 703-708.

Cerqueira, C. R., Olivato, P. R., Rodrigues, D. N. S., ZukermanSchpector, J., Tiekink, E. R. T. \& Dal Colle, M. (2017). J. Mol. Struct. 1133, 49-65.

ChemAxon (2010). Marvinsketch. http://www.chemaxon.com.

Contreras-García, J., Johnson, E. R., Keinan, S., Chaudret, R., Piquemal, J.-P., Beratan, D. N. \& Yang, W. (2011). J. Chem. Theory Comput. 7, 625-632.

Farrugia, L. J. (2012). J. Appl. Cryst. 45, 849-854.

Johnson, E. R., Keinan, S., Mori-Sánchez, P., Contreras-García, J., Cohen, A. J. \& Yang, W. (2010). J. Am. Chem. Soc. 132, 6498-6506.

Parsons, S., Flack, H. D. \& Wagner, T. (2013). Acta Cryst. B69, 249 259.

Sheldrick, G. M. (1996). SADABS. University of Göttingen, Germany.

Sheldrick, G. M. (2015). Acta Cryst. C71, 3-8.

Tan, S. L., Jotani, M. M. \& Tiekink, E. R. T. (2019). Acta Cryst. E75, 308-318.

Traesel, H. J., Olivato, P. R., Valença, J., Rodrigues, D. N. S., Zukerman-Schpector, J. \& Dal Colle, M. (2018). J. Mol. Struct. 1157, 29-39.

Turner, M. J., Mckinnon, J. J., Wolff, S. K., Grimwood, D. J., Spackman, P. R., Jayatilaka, D. \& Spackman, M. A. (2017). Crystal Explorer 17. The University of Western Australia.

Vinhato, E., Olivato, P. R., Zukerman-Schpector, J. \& Dal Colle, M. (2013). Spectrochim. Acta Part A, 115, 738-746.

Westrip, S. P. (2010). J. Appl. Cryst. 43, 920-925.

Zoretic, P. A. \& Soja, P. (1976). J. Org. Chem. 41, 3587-3589.

Zukerman-Schpector, J., Olivato, P. R., Traesel, H. J., Valença, J., Rodrigues, D. N. S. \& Tiekink, E. R. T. (2015). Acta Cryst. E71, o3o4. 


\section{supporting information}

Acta Cryst. (2019). E75, 816-822［https://doi.org/10.1107/S2056989019006765]

\section{2-[(4-Bromophenyl)sulfanyl]-2-methoxy-1-phenylethan-1-one: crystal structure,} Hirshfeld surface analysis and computational chemistry

Ignez Caracelli, Julio Zukerman-Schpector, Henrique J. Traesel, Paulo R. Olivato, Mukesh M.

Jotani and Edward R. T. Tiekink

Computing details

Data collection: APEX2 (Bruker, 2009); cell refinement: SAINT (Bruker, 2009); data reduction: SAINT (Bruker, 2009); program(s) used to solve structure: SIR2014 (Burla et al., 2015); program(s) used to refine structure: SHELXL2014 (Sheldrick, 2015); molecular graphics: ORTEP-3 for Windows (Farrugia, 2012) and DIAMOND (Brandenburg, 2006); software used to prepare material for publication: MarvinSketch (ChemAxon, 2010) and publCIF (Westrip, 2010).

2-[(4-Bromophenyl)sulfanyl]-2-methoxy-1-phenylethan-1-one

Crystal data

$\mathrm{C}_{15} \mathrm{H}_{13} \mathrm{BrO}_{2} \mathrm{~S}$

$M_{r}=337.21$

Orthorhombic, $P c a 2_{1}$

$a=18.0683(13) \AA$

$b=8.0190(6) \AA$

$c=9.8513(5) \AA$

$V=1427.35(16) \AA^{3}$

$Z=4$

$F(000)=680$

Data collection

Bruker APEXII CCD diffractometer

$\varphi$ and $\omega$ scans

Absorption correction: multi-scan

(SADABS; Sheldrick, 1996)

$T_{\min }=0.545, T_{\max }=0.745$

6329 measured reflections

Refinement

Refinement on $F^{2}$

Least-squares matrix: full

$R\left[F^{2}>2 \sigma\left(F^{2}\right)\right]=0.035$

$w R\left(F^{2}\right)=0.086$

$S=0.90$

2820 reflections

173 parameters

1 restraint

Primary atom site location: structure-invariant direct methods
$D_{\mathrm{x}}=1.569 \mathrm{Mg} \mathrm{m}^{-3}$

Mo $K \alpha$ radiation, $\lambda=0.71073 \AA$

Cell parameters from 1496 reflections

$\theta=2.8-23.5^{\circ}$

$\mu=3.02 \mathrm{~mm}^{-1}$

$T=293 \mathrm{~K}$

Irregular, colourless

$0.47 \times 0.20 \times 0.14 \mathrm{~mm}$

2820 independent reflections

1903 reflections with $I>2 \sigma(I)$

$R_{\text {int }}=0.037$

$\theta_{\text {max }}=26.4^{\circ}, \theta_{\min }=2.3^{\circ}$

$h=-22 \rightarrow 22$

$k=-10 \rightarrow 7$

$l=-10 \rightarrow 12$

Secondary atom site location: difference Fourier map

Hydrogen site location: inferred from neighbouring sites

$\mathrm{H}$-atom parameters constrained

$w=1 /\left[\sigma^{2}\left(F_{\mathrm{o}}^{2}\right)\right]$

where $P=\left(F_{\mathrm{o}}^{2}+2 F_{\mathrm{c}}{ }^{2}\right) / 3$

$(\Delta / \sigma)_{\max }<0.001$

$\Delta \rho_{\max }=0.24$ e $\AA^{-3}$

$\Delta \rho_{\min }=-0.36 \mathrm{e} \AA^{-3}$ 
Absolute structure: Flack $x$ determined using

702 quotients $\left[\left(I^{+}\right)-(I)\right] /\left[\left(I^{+}\right)+\left(I^{-}\right)\right]$(Parsons et al., 2013)

Absolute structure parameter: 0.013 (11)

\section{Special details}

Geometry. All esds (except the esd in the dihedral angle between two 1.s. planes) are estimated using the full covariance matrix. The cell esds are taken into account individually in the estimation of esds in distances, angles and torsion angles; correlations between esds in cell parameters are only used when they are defined by crystal symmetry. An approximate (isotropic) treatment of cell esds is used for estimating esds involving l.s. planes.

Fractional atomic coordinates and isotropic or equivalent isotropic displacement parameters $\left(\AA^{2}\right)$

\begin{tabular}{|c|c|c|c|c|}
\hline & $x$ & $y$ & $z$ & $U_{\text {iso }} * / U_{\text {eq }}$ \\
\hline $\mathrm{C} 1$ & 0.3809 (4) & $0.7980(8)$ & $0.2687(6)$ & $0.0481(16)$ \\
\hline $\mathrm{C} 2$ & $0.3282(4)$ & $0.7230(8)$ & $0.3471(6)$ & $0.0547(17)$ \\
\hline $\mathrm{H} 2$ & 0.2844 & 0.6846 & 0.3086 & $0.066^{*}$ \\
\hline $\mathrm{C} 3$ & $0.3411(4)$ & $0.7049(8)$ & $0.4862(6)$ & $0.0573(18)$ \\
\hline H3 & 0.3059 & 0.6531 & 0.5406 & $0.069^{*}$ \\
\hline $\mathrm{C} 4$ & $0.4057(3)$ & $0.7634(8)$ & $0.5432(5)$ & 0.0442 \\
\hline C5 & $0.4582(4)$ & $0.8394(7)$ & $0.4612(6)$ & $0.0481(15)$ \\
\hline H5 & 0.5020 & 0.8793 & 0.4989 & $0.058^{*}$ \\
\hline C6 & $0.4456(4)$ & $0.8561(8)$ & $0.3225(5)$ & $0.0470(15)$ \\
\hline H6 & 0.4808 & 0.9063 & 0.2671 & $0.056^{*}$ \\
\hline $\mathrm{C} 7$ & $0.6000(4)$ & $0.6921(10)$ & $0.7438(8)$ & $0.074(2)$ \\
\hline H7A & 0.6041 & 0.6513 & 0.8351 & $0.111 *$ \\
\hline $\mathrm{H} 7 \mathrm{C}$ & 0.5822 & 0.8049 & 0.7453 & $0.111^{*}$ \\
\hline H7B & 0.6477 & 0.6889 & 0.7009 & $0.111^{*}$ \\
\hline $\mathrm{C} 8$ & $0.4826(3)$ & $0.5677(7)$ & $0.7324(5)$ & $0.0446(14)$ \\
\hline H8 & 0.4910 & 0.5417 & 0.8284 & $0.053^{*}$ \\
\hline C9 & $0.4446(3)$ & $0.4212(7)$ & $0.6661(5)$ & $0.0417(14)$ \\
\hline $\mathrm{C} 10$ & $0.3832(3)$ & $0.3328(7)$ & $0.7355(6)$ & $0.0424(13)$ \\
\hline C11 & $0.3535(3)$ & $0.1926(8)$ & $0.6732(7)$ & $0.0547(17)$ \\
\hline H11 & 0.3720 & 0.1580 & 0.5897 & $0.066^{*}$ \\
\hline $\mathrm{C} 12$ & $0.2968(4)$ & $0.1035(8)$ & $0.7336(7)$ & $0.0660(18)$ \\
\hline H12 & 0.2773 & 0.0102 & 0.6904 & $0.079 *$ \\
\hline $\mathrm{C} 13$ & $0.2689(4)$ & $0.1533(9)$ & $0.8592(7)$ & $0.067(2)$ \\
\hline H13 & 0.2308 & 0.0938 & 0.9005 & $0.080 *$ \\
\hline $\mathrm{C} 14$ & $0.2986(4)$ & $0.2922(9)$ & $0.9210(7)$ & $0.069(2)$ \\
\hline H14 & 0.2800 & 0.3273 & 1.0043 & $0.083 *$ \\
\hline $\mathrm{C} 15$ & $0.3551(4)$ & $0.3791(10)$ & $0.8614(7)$ & $0.0613(18)$ \\
\hline H15 & 0.3751 & 0.4708 & 0.9060 & $0.074 *$ \\
\hline $\mathrm{O} 1$ & $0.5500(2)$ & $0.5910(6)$ & $0.6703(4)$ & $0.0573(11)$ \\
\hline $\mathrm{O} 2$ & $0.4633(2)$ & $0.3773(6)$ & $0.5525(4)$ & $0.0623(12)$ \\
\hline S1 & $0.41992(10)$ & $0.7500(2)$ & $0.72103(15)$ & 0.0551 \\
\hline $\mathrm{Br} 1$ & $0.36371(4)$ & $0.82410(9)$ & $0.07901(8)$ & 0.0718 \\
\hline
\end{tabular}


Atomic displacement parameters $\left(\AA^{2}\right)$

\begin{tabular}{lllllll}
\hline & $U^{11}$ & $U^{22}$ & $U^{33}$ & $U^{12}$ & $U^{13}$ & $U^{23}$ \\
\hline $\mathrm{C} 1$ & $0.060(4)$ & $0.045(4)$ & $0.039(3)$ & $0.011(3)$ & $-0.008(3)$ & $0.001(3)$ \\
$\mathrm{C} 2$ & $0.046(4)$ & $0.060(5)$ & $0.059(4)$ & $0.001(3)$ & $-0.001(3)$ & $0.005(3)$ \\
$\mathrm{C} 3$ & $0.062(4)$ & $0.054(5)$ & $0.056(4)$ & $-0.002(4)$ & $0.005(3)$ & $0.012(3)$ \\
$\mathrm{C} 4$ & $0.050(3)$ & $0.044(4)$ & $0.039(3)$ & $0.007(3)$ & $0.006(3)$ & $0.000(2)$ \\
$\mathrm{C} 5$ & $0.048(4)$ & $0.045(4)$ & $0.052(3)$ & $0.001(3)$ & $-0.006(3)$ & $0.000(3)$ \\
$\mathrm{C} 6$ & $0.048(4)$ & $0.047(4)$ & $0.045(3)$ & $0.005(3)$ & $0.009(3)$ & $0.005(2)$ \\
$\mathrm{C} 7$ & $0.073(5)$ & $0.091(6)$ & $0.058(5)$ & $-0.028(4)$ & $-0.002(4)$ & $0.001(4)$ \\
C8 & $0.051(4)$ & $0.050(4)$ & $0.032(2)$ & $-0.004(3)$ & $-0.002(3)$ & $0.005(3)$ \\
C9 & $0.054(4)$ & $0.041(4)$ & $0.030(3)$ & $0.012(3)$ & $-0.005(3)$ & $0.003(2)$ \\
C10 & $0.049(3)$ & $0.038(3)$ & $0.041(3)$ & $0.005(3)$ & $-0.010(3)$ & $0.005(3)$ \\
C11 & $0.055(4)$ & $0.055(4)$ & $0.055(4)$ & $0.006(3)$ & $-0.005(3)$ & $-0.008(3)$ \\
C12 & $0.055(4)$ & $0.069(5)$ & $0.074(4)$ & $-0.012(4)$ & $-0.012(4)$ & $-0.003(4)$ \\
C13 & $0.052(5)$ & $0.071(5)$ & $0.077(5)$ & $-0.009(3)$ & $-0.004(4)$ & $0.028(4)$ \\
C14 & $0.074(5)$ & $0.079(6)$ & $0.056(4)$ & $-0.010(4)$ & $0.005(4)$ & $0.002(4)$ \\
C15 & $0.071(5)$ & $0.072(5)$ & $0.042(3)$ & $-0.012(4)$ & $0.003(3)$ & $-0.004(3)$ \\
O1 & $0.058(3)$ & $0.070(3)$ & $0.044(2)$ & $-0.009(2)$ & $0.003(2)$ & $-0.001(2)$ \\
O2 & $0.081(3)$ & $0.068(3)$ & $0.037(2)$ & $-0.004(2)$ & $0.007(2)$ & $-0.009(2)$ \\
S1 & $0.0774(11)$ & $0.0497(9)$ & $0.0382(7)$ & $0.0083(9)$ & $0.0041(9)$ & $-0.0035(7)$ \\
Br1 & $0.0797(5)$ & $0.0905(5)$ & $0.0450(3)$ & $0.0229(4)$ & $-0.0087(4)$ & $0.0030(4)$ \\
& & & & & & \\
\hline
\end{tabular}

Geometric parameters $\left(A,{ }^{\circ}\right)$

\begin{tabular}{llll}
\hline $\mathrm{C} 1-\mathrm{C} 6$ & $1.365(9)$ & $\mathrm{C} 8-\mathrm{C} 9$ & $1.510(7)$ \\
$\mathrm{C} 1-\mathrm{C} 2$ & $1.366(9)$ & $\mathrm{C} 8-\mathrm{S} 1$ & $1.853(6)$ \\
$\mathrm{C} 1-\mathrm{Br} 1$ & $1.905(6)$ & $\mathrm{C} 8-\mathrm{H} 8$ & 0.9800 \\
$\mathrm{C} 2-\mathrm{C} 3$ & $1.398(8)$ & $\mathrm{C} 9-\mathrm{O} 2$ & $1.221(6)$ \\
$\mathrm{C} 2-\mathrm{H} 2$ & 0.9300 & $\mathrm{C} 9-\mathrm{C} 10$ & $1.382(8)$ \\
$\mathrm{C} 3-\mathrm{C} 4$ & $1.378(9)$ & $\mathrm{C} 10-\mathrm{C} 11$ & $1.391(9)$ \\
$\mathrm{C} 3-\mathrm{H} 3$ & 0.9300 & $\mathrm{C} 10-\mathrm{C} 15$ & $1.384(9)$ \\
$\mathrm{C} 4-\mathrm{C} 5$ & $1.388(8)$ & $\mathrm{C} 11-\mathrm{C} 12$ & 0.9300 \\
$\mathrm{C} 4-\mathrm{S} 1$ & $1.773(5)$ & $\mathrm{C} 11-\mathrm{H} 11$ & $1.395(10)$ \\
$\mathrm{C} 5-\mathrm{C} 6$ & $1.392(8)$ & $\mathrm{C} 12-\mathrm{C} 13$ & 0.9300 \\
$\mathrm{C} 5-\mathrm{H} 5$ & 0.9300 & $\mathrm{C} 12-\mathrm{H} 12$ & $1.378(9)$ \\
$\mathrm{C} 6-\mathrm{H} 6$ & 0.9300 & $\mathrm{C} 13-\mathrm{C} 14$ & 0.9300 \\
$\mathrm{C} 7-\mathrm{O} 1$ & $1.414(8)$ & $\mathrm{C} 13-\mathrm{H} 13$ & $1.369(10)$ \\
$\mathrm{C} 7-\mathrm{H} 7 \mathrm{~A}$ & 0.9600 & $\mathrm{C} 14-\mathrm{C} 15$ & 0.9300 \\
$\mathrm{C} 7-\mathrm{H} 7 \mathrm{C}$ & 0.9600 & $\mathrm{C} 14-\mathrm{H} 14$ & \\
$\mathrm{C} 7-\mathrm{H} 7 \mathrm{~B}$ & 0.9600 & $\mathrm{C} 15-\mathrm{H} 15$ & 108.7 \\
$\mathrm{C} 8-\mathrm{O} 1$ & $1.375(6)$ & & 108.7 \\
& & & 108.7 \\
$\mathrm{C} 6-\mathrm{C} 1-\mathrm{C} 2$ & $121.8(5)$ & $\mathrm{O} 1-\mathrm{C} 8-\mathrm{H} 8$ & $119.5(5)$ \\
$\mathrm{C} 6-\mathrm{C} 1-\mathrm{Br} 1$ & $118.9(5)$ & $\mathrm{C} 9-\mathrm{C} 8-\mathrm{H} 8$ & $119.6(5)$ \\
$\mathrm{C} 2-\mathrm{C} 1-\mathrm{Br} 1$ & $119.3(5)$ & $\mathrm{S} 1-\mathrm{C} 8-\mathrm{H} 8$ & \\
$\mathrm{C} 1-\mathrm{C} 2-\mathrm{C} 3$ & $118.9(7)$ & $\mathrm{O} 2-\mathrm{C} 9-\mathrm{C} 10$ & $\mathrm{O} 2-\mathrm{C} 9-\mathrm{C} 8$ \\
$\mathrm{C} 1-\mathrm{C} 2-\mathrm{H} 2$ & 120.5 & &
\end{tabular}




\begin{tabular}{|c|c|c|c|}
\hline $\mathrm{C} 3-\mathrm{C} 2-\mathrm{H} 2$ & 120.5 & $\mathrm{C} 10-\mathrm{C} 9-\mathrm{C} 8$ & $120.8(5)$ \\
\hline $\mathrm{C} 4-\mathrm{C} 3-\mathrm{C} 2$ & $120.4(6)$ & $\mathrm{C} 11-\mathrm{C} 10-\mathrm{C} 15$ & $118.0(6)$ \\
\hline $\mathrm{C} 4-\mathrm{C} 3-\mathrm{H} 3$ & 119.8 & $\mathrm{C} 11-\mathrm{C} 10-\mathrm{C} 9$ & $118.1(5)$ \\
\hline $\mathrm{C} 2-\mathrm{C} 3-\mathrm{H} 3$ & 119.8 & $\mathrm{C} 15-\mathrm{C} 10-\mathrm{C} 9$ & $123.8(5)$ \\
\hline $\mathrm{C} 3-\mathrm{C} 4-\mathrm{C} 5$ & $119.4(5)$ & $\mathrm{C} 12-\mathrm{C} 11-\mathrm{C} 10$ & $120.9(6)$ \\
\hline $\mathrm{C} 3-\mathrm{C} 4-\mathrm{S} 1$ & $120.3(5)$ & $\mathrm{C} 12-\mathrm{C} 11-\mathrm{H} 11$ & 119.5 \\
\hline $\mathrm{C} 5-\mathrm{C} 4-\mathrm{S} 1$ & $120.2(5)$ & $\mathrm{C} 10-\mathrm{C} 11-\mathrm{H} 11$ & 119.5 \\
\hline $\mathrm{C} 4-\mathrm{C} 5-\mathrm{C} 6$ & $120.1(6)$ & $\mathrm{C} 11-\mathrm{C} 12-\mathrm{C} 13$ & $120.1(6)$ \\
\hline $\mathrm{C} 4-\mathrm{C} 5-\mathrm{H} 5$ & 120.0 & $\mathrm{C} 11-\mathrm{C} 12-\mathrm{H} 12$ & 119.9 \\
\hline $\mathrm{C} 6-\mathrm{C} 5-\mathrm{H} 5$ & 120.0 & $\mathrm{C} 13-\mathrm{C} 12-\mathrm{H} 12$ & 119.9 \\
\hline $\mathrm{C} 1-\mathrm{C} 6-\mathrm{C} 5$ & $119.3(6)$ & $\mathrm{C} 14-\mathrm{C} 13-\mathrm{C} 12$ & $118.9(6)$ \\
\hline $\mathrm{C} 1-\mathrm{C} 6-\mathrm{H} 6$ & 120.4 & $\mathrm{C} 14-\mathrm{C} 13-\mathrm{H} 13$ & 120.6 \\
\hline $\mathrm{C} 5-\mathrm{C} 6-\mathrm{H} 6$ & 120.4 & $\mathrm{C} 12-\mathrm{C} 13-\mathrm{H} 13$ & 120.6 \\
\hline $\mathrm{O} 1-\mathrm{C} 7-\mathrm{H} 7 \mathrm{~A}$ & 109.5 & $\mathrm{C} 15-\mathrm{C} 14-\mathrm{C} 13$ & $120.8(7)$ \\
\hline $\mathrm{O} 1-\mathrm{C} 7-\mathrm{H} 7 \mathrm{C}$ & 109.5 & $\mathrm{C} 15-\mathrm{C} 14-\mathrm{H} 14$ & 119.6 \\
\hline $\mathrm{H} 7 \mathrm{~A}-\mathrm{C} 7-\mathrm{H} 7 \mathrm{C}$ & 109.5 & $\mathrm{C} 13-\mathrm{C} 14-\mathrm{H} 14$ & 119.6 \\
\hline $\mathrm{O} 1-\mathrm{C} 7-\mathrm{H} 7 \mathrm{~B}$ & 109.5 & $\mathrm{C} 14-\mathrm{C} 15-\mathrm{C} 10$ & $121.3(7)$ \\
\hline $\mathrm{H} 7 \mathrm{~A}-\mathrm{C} 7-\mathrm{H} 7 \mathrm{~B}$ & 109.5 & $\mathrm{C} 14-\mathrm{C} 15-\mathrm{H} 15$ & 119.4 \\
\hline $\mathrm{H} 7 \mathrm{C}-\mathrm{C} 7-\mathrm{H} 7 \mathrm{~B}$ & 109.5 & $\mathrm{C} 10-\mathrm{C} 15-\mathrm{H} 15$ & 119.4 \\
\hline $\mathrm{O} 1-\mathrm{C} 8-\mathrm{C} 9$ & $108.4(4)$ & $\mathrm{C} 8-\mathrm{O} 1-\mathrm{C} 7$ & $114.6(5)$ \\
\hline $\mathrm{O} 1-\mathrm{C} 8-\mathrm{S} 1$ & $114.0(4)$ & $\mathrm{C} 4-\mathrm{S} 1-\mathrm{C} 8$ & $101.3(3)$ \\
\hline $\mathrm{C} 9-\mathrm{C} 8-\mathrm{S} 1$ & $108.1(4)$ & & \\
\hline $\mathrm{C} 6-\mathrm{C} 1-\mathrm{C} 2-\mathrm{C} 3$ & $-0.2(10)$ & $\mathrm{O} 2-\mathrm{C} 9-\mathrm{C} 10-\mathrm{C} 15$ & $-176.3(6)$ \\
\hline $\mathrm{Br} 1-\mathrm{C} 1-\mathrm{C} 2-\mathrm{C} 3$ & $-179.8(5)$ & $\mathrm{C} 8-\mathrm{C} 9-\mathrm{C} 10-\mathrm{C} 15$ & $1.9(8)$ \\
\hline $\mathrm{C} 1-\mathrm{C} 2-\mathrm{C} 3-\mathrm{C} 4$ & $0.6(10)$ & $\mathrm{C} 15-\mathrm{C} 10-\mathrm{C} 11-\mathrm{C} 12$ & $1.2(9)$ \\
\hline $\mathrm{C} 2-\mathrm{C} 3-\mathrm{C} 4-\mathrm{C} 5$ & $-0.5(9)$ & $\mathrm{C} 9-\mathrm{C} 10-\mathrm{C} 11-\mathrm{C} 12$ & $179.2(5)$ \\
\hline $\mathrm{C} 2-\mathrm{C} 3-\mathrm{C} 4-\mathrm{S} 1$ & $176.7(5)$ & $\mathrm{C} 10-\mathrm{C} 11-\mathrm{C} 12-\mathrm{C} 13$ & $-0.4(9)$ \\
\hline $\mathrm{C} 3-\mathrm{C} 4-\mathrm{C} 5-\mathrm{C} 6$ & $-0.1(9)$ & $\mathrm{C} 11-\mathrm{C} 12-\mathrm{C} 13-\mathrm{C} 14$ & $0.2(10)$ \\
\hline $\mathrm{S} 1-\mathrm{C} 4-\mathrm{C} 5-\mathrm{C} 6$ & $-177.2(5)$ & $\mathrm{C} 12-\mathrm{C} 13-\mathrm{C} 14-\mathrm{C} 15$ & $-0.7(11)$ \\
\hline $\mathrm{C} 2-\mathrm{C} 1-\mathrm{C} 6-\mathrm{C} 5$ & $-0.3(9)$ & $\mathrm{C} 13-\mathrm{C} 14-\mathrm{C} 15-\mathrm{C} 10$ & $1.6(11)$ \\
\hline $\mathrm{Br} 1-\mathrm{C} 1-\mathrm{C} 6-\mathrm{C} 5$ & $179.3(4)$ & $\mathrm{C} 11-\mathrm{C} 10-\mathrm{C} 15-\mathrm{C} 14$ & $-1.7(10)$ \\
\hline $\mathrm{C} 4-\mathrm{C} 5-\mathrm{C} 6-\mathrm{C} 1$ & $0.5(9)$ & $\mathrm{C} 9-\mathrm{C} 10-\mathrm{C} 15-\mathrm{C} 14$ & $-179.6(6)$ \\
\hline $\mathrm{O} 1-\mathrm{C} 8-\mathrm{C} 9-\mathrm{O} 2$ & $-20.8(7)$ & $\mathrm{C} 9-\mathrm{C} 8-\mathrm{O} 1-\mathrm{C} 7$ & $-163.5(5)$ \\
\hline $\mathrm{S} 1-\mathrm{C} 8-\mathrm{C} 9-\mathrm{O} 2$ & $103.2(5)$ & $\mathrm{S} 1-\mathrm{C} 8-\mathrm{O} 1-\mathrm{C} 7$ & $76.1(6)$ \\
\hline $\mathrm{O} 1-\mathrm{C} 8-\mathrm{C} 9-\mathrm{C} 10$ & $160.9(4)$ & $\mathrm{C} 3-\mathrm{C} 4-\mathrm{S} 1-\mathrm{C} 8$ & $102.0(5)$ \\
\hline $\mathrm{S} 1-\mathrm{C} 8-\mathrm{C} 9-\mathrm{C} 10$ & $-75.0(5)$ & $\mathrm{C} 5-\mathrm{C} 4-\mathrm{S} 1-\mathrm{C} 8$ & $-80.9(5)$ \\
\hline $\mathrm{O} 2-\mathrm{C} 9-\mathrm{C} 10-\mathrm{C} 11$ & $5.7(8)$ & $\mathrm{O} 1-\mathrm{C} 8-\mathrm{S} 1-\mathrm{C} 4$ & $63.5(4)$ \\
\hline $\mathrm{C} 8-\mathrm{C} 9-\mathrm{C} 10-\mathrm{C} 11$ & $-176.0(5)$ & $\mathrm{C} 9-\mathrm{C} 8-\mathrm{S} 1-\mathrm{C} 4$ & $-57.1(4)$ \\
\hline
\end{tabular}

Hydrogen-bond geometry $\left(\AA,{ }^{\circ}\right)$

\begin{tabular}{lllll}
\hline$D-\mathrm{H} \cdots A$ & $D-\mathrm{H}$ & $\mathrm{H} \cdots A$ & $D \cdots A$ & $D-\mathrm{H} \cdots A$ \\
\hline $\mathrm{C} 7-\mathrm{H} 7 A \cdots \mathrm{O} 2^{\mathrm{i}}$ & 0.96 & 2.47 & $3.296(9)$ & 144 \\
$\mathrm{C} 8-\mathrm{H} 8 \cdots \mathrm{O} 2^{\mathrm{i}}$ & 0.98 & 2.44 & $3.331(6)$ & 150 \\
\hline
\end{tabular}

Symmetry code: (i) $-x+1,-y+1, z+1 / 2$. 